\title{
Aspek Ekologis dan Determinan Produksi Kopi Arabika Spesialti di Wilayah Dataran Tinggi Sumatera Utara
}

\author{
Jef Rudiantho Saragih \\ Program Studi Agribisnis, Fakultas Pertanian \\ Universitas Simalungun, Pematangsiantar, Indonesia
}

Artikel Masuk : 3 November 2017

Artikel Diterima : 9 Januari 2018

Tersedia Online : 31 Agustus 2018

\begin{abstract}
Abstrak: Usaha tani kopi arabika secara monokultur tidak mendukung keberlanjutan ekologi. Pasar internasional menginginkan produk kopi arabika sesuai dengan standar ramah lingkungan yang memperhatikan aspek ekologis dalam pengelolaannya. Penelitian ini bertujuan untuk mengidentifikasi aspek ekologis usaha tani kopi arabika spesialti dan menganalisis pengaruh jumlah pohon pelindung, penggunaan pupuk organik, pemangkasan tanaman kopi, konservasi lahan, dan pengendalian hama penggerek buah kopi terhadap produksi kopi arabika. Data aspek ekologis usaha tani berasal dari tiga kabupaten di Provinsi Sumatera Utara, yaitu Kabupaten Simalungun, Kabupaten Tapanuli Utara, dan Kabupaten Dairi. Determinan produksi dianalisis dari data usaha tani di tiga kecamatan di Kabupaten Simalungun, yaitu Kecamatan Sidamanik, Pamatang Sidamanik, dan Dolok Pardamean. Lokasi penelitian ditentukan dengan metode multi-stage cluster sampling dan sampel petani ditentukan dengan metode sampel acak sederhana. Aspek ekologis dianalisis secara deskriptif, sedangkan determinan produksi dianalisis dengan persamaan regresi ganda. Hasil analisis menunjukkan bahwa usaha tani kopi arabika berpelindung sebanyak $32 \%$ dari keseluruhan usaha tani kopi arabika di wilayah penelitian dengan jumlah populasi rata-rata 45 pohon/ha. Kegiatan konservasi lahan yang dilakukan petani adalah dengan penggunaan mulsa kulit buah kopi $(92 \%)$, teras individu (3\%), rorak $(4 \%)$, dan teras bangku (1\%). Sistem usaha tani kopi arabika yang dilakukan petani adalah kopi monokultur (30\%), kopi tumpangsari $(24 \%)$, kopi berpelindung (32\%), dan kopi multistrata (14\%). Pemangkasan tanaman kopi dan pengendalian hama penggerek buah kopi (PBKo) menjadi determinan penting untuk meningkatkan produksi kopi arabika spesialti. Kegiatan konservasi lahan, jumlah pohon pelindung, dan pupuk organik merupakan determinan produksi kopi arabika spesialti yang tidak signifikan dalam jangka pendek. Ketiga variabel ekologis ini berperan dalam menjaga kelestarian lahan dan mendukung produksi kopi arabika berkelanjutan dalam jangka panjang.
\end{abstract}

Kata Kunci: aspek ekologis; kopi arabika spesialti; produksi; Sumatera Utara

Abstract: Monoculture farming of arabica coffee plantation does not support ecological sustainability. International market demands arabica coffee product in compliance with an environmentally friendly standard which promotes ecological-based management. This study aims to identify the ecological aspects of specialty arabica coffee cultivation, and to analyze the 


\section{Aspek Ekologis dan Determinan Produksi Kopi Arabika Spesialti di Wilayah Dataran Tinggi. . .}

effect of shade tree population, the use of organic fertilizer, the pruning of coffee crop, land conservation, and the control of coffee berry borer on specialty arabica coffee production. The data of ecological aspect was collected from three regencies in North Sumatera Province, namely Simalungun, North Tapanuli, and Dairi. Production determinant was analyzed concerning farming cultivation in three districts of Simalungun Regency namely Sidamanik, Pamatang Sidamanik, and Dolok Pardamean. The location was determined with multi-stage cluster sampling and the farmer samples with simple random sampling. The ecological aspect was analyzed descriptively while the determinant of arabica coffee production was analyzed with multiple regression method. The result shows that the shaded arabica coffee farming covers only $32 \%$ of the total arabica coffee production in the study area with a population of 45 trees/ha. Land conservation conducted by the farmers utilizes coffee fruit mulch (92\%), individual terrace (3\%), rorak (4\%), and bench terrace (1\%). The arabica coffee farming system managed by the farmers consists of monoculture (30\%), mix farming (24\%), shade coffee (32\%), and multistrata coffee (14\%). The pruning of coffee plants and integrated control of coffee berry borer has a significant effect on specialty arabica coffee production. Land conservation, population of shade tree, and organic fertilizer are an important production determinant on arabica coffee production in the short-term. These three ecological variables play a role to maintain land preservation and support sustainable arabica coffee production in the long-term.

Keywords: ecological aspect; North Sumatera; production; specialty arabica coffee

\section{Pendahuluan}

Indonesia merupakan produsen kopi terbesar keempat dunia setelah Brazil, Vietnam, dan Kolombia pada tahun 2015-2016. Volume produksi kopi Indonesia mencapai 739 ribu ton. Produksi kopi Brazil merupakan yang tertinggi mencapai lebih dari 3 juta ton dan Vietnam sebesar 1,7 juta ton. Kolombia berada pada posisi ketiga dengan produksi 840 ribu ton (ICO, 2017).

Provinsi Sumatera Utara merupakan produsen terbesar kopi arabika di Indonesia dengan produksi kopi pada tahun 2016 mencapai 50.405 ton (Kementerian Pertanian, 2016). Produksi kopi di Sumatera Utara memberikan kontribusi 30\% dari produksi nasional. Posisi kedua ditempati oleh Aceh sebanyak 44.540 ton (27\%), disusul oleh Sulawesi Selatan 21.802 ton $(12 \%)$, dan Sumatera Barat 15.930 ton (9\%). Berdasarkan aspek pangsa produksi, kopi arabika Sumatera Utara dipasok dari Kabupaten Tapanuli Utara (20,61\%), Kabupaten Dairi $(19,52 \%)$, Kabupaten Simalungun (17,27\%), Kabupaten Karo (13,96\%), Kabupaten Humbang Hasundutan (12,03\%), dan kabupaten lainnya (16,62\%) (Kementerian Pertanian, 2016).

Kopi arabika Sumatera Utara memiliki reputasi internasional dengan nama Mandheling Coffee dan Lintong Coffee. Asal kopi Mandheling adalah wilayah di dataran tinggi Bukit Barisan Sumatera Utara dengan elevasi 1.000-1.600 $\mathrm{m}$ di atas permukaan laut (dpl). Kopi arabika dari wilayah Simalungun termasuk ke dalam kelompok Mandheling Coffee (Mawardi, 2008). Mandheling Coffee merupakan kopi spesialti (Mawardi, 2007, 2009; Wahyudi \& Misnawi, 2007), sedangkan Lintong Coffee berasal dari Lintong Ni Huta di Humbang Hasundutan. Wilayah geografisnya di dataran tinggi Bukit Barisan Sumatera Utara, terutama di sekitar Danau Toba dengan elevasi 1.300-1.600 m dpl. Kopi jenis ini berasal dari wilayah Toba (Mawardi, 2008).

Kopi spesialti (spesialty coffee) merupakan istilah yang pertama kali diperkenalkan oleh Erna Knutsen pada konferensi kopi internasional di Perancis tahun 1978. Secara umum konsepnya sangat sederhana, yaitu dengan memanfaatkan iklim mikro geografis khusus yang menghasilkan biji kopi dengan profil cita rasa unik (Rhinehart, 2009). Kementerian Pertanian (2010) mendefinisikan kopi spesialti sebagai kopi yang mempunyai cita rasa yang khas, tumbuh pada daerah yang khas dan sudah dikenal masyarakat internasional. Lewin, Giovannucci, \& Panayotis (2004) menyatakan bahwa kopi spesialti mengacu pada kopi yang berbeda dari kopi biasa karena kualitasnya yang tinggi atau karena proses produksinya 
berbeda. Ottaway (2007) menyatakan kopi arabika dari Aceh dan Sumatera Utara merupakan kopi arabika spesialti yang memiliki permintaan tinggi karena memiliki karakter yang unik.

Usaha tani kopi arabika secara monokultur dapat menghasilkan produksi yang lebih tinggi, namun dinilai tidak mendukung keberlanjutan lingkungan, padahal usaha tani kopi yang ramah lingkungan menjadi isu sentral dalam perdagangan kopi global. Usaha tani yang ramah lingkungan adalah usaha tani yang memperhatikan aspek ekologi dalam pengelolaannya. Penelitian Wollni \& Brümmer (2009) menggunakan variabel pemangkasan tanaman kopi dan menyimpulkan bahwa pemangkasan tanaman kopi berpengaruh nyata terhadap produksi kopi arabika. Penelitian Poudel, Yamamoto, Naoyuki, Nishiwaki, \& Kano (2010) menggunakan variabel pupuk organik dan menyimpulkan bahwa pupuk organik berpengaruh nyata terhadap produksi kopi arabika.

Perkebunan kopi berkelanjutan menekankan produksi dalam jangka panjang dan tetap menguntungkan serta bersifat ramah lingkungan. Sistem ini tidak hanya menghasilkan biji kopi, tetapi juga memberikan layanan kepada lingkungan seperti konservasi tanah dan air serta konservasi keanekaragaman hayati. Proses ekologis seperti siklus nutrisi dan air, aliran energi, dan mekanisme pengaturan populasi berfungsi mirip dengan yang terjadi di hutan tropis (Perfecto, Vandermeer, Mas, \& Soto Pinto, 2005).

Penelitian ini bertujuan untuk menganalisis aspek ekologis usaha tani kopi arabika di Provinsi Sumatera Utara serta untuk menganalisis pengaruh variabel pohon pelindung, perbandingan biaya pupuk organik dengan pupuk anorganik, pemangkasan tanaman kopi, konservasi lahan, dan pengendalian penggerek buah kopi (PBKo) terhadap produksi kopi arabika spesialti di Kabupaten Simalungun. Karakteristik ekologis yang dimaksud dalam penelitian ini adalah jumlah pohon pelindung, kegiatan konservasi lahan, dan sistem usaha tani kopi arabika.

Penelitian ini dinilai penting mengingat pada dekade ini konsumen kopi menaruh perhatian terhadap kondisi sosial-ekonomi dan ekologi yang dihadapi oleh petani di negaranegara sedang berkembang untuk mendorong pertumbuhan berkelanjutan yang berorientasi pada standar tertentu (ITC, 2011). Hasil penelitian Arief, Tarigan, Saragih, \& Rahmadani (2011) menyatakan bahwa kondisi pengelolaan kebun kopi di Provinsi Sumatera Utara masih dilakukan oleh petani dengan pola tradisional yang menggunakan sarana produksi kimia dalam pemeliharaannya. Kondisi ini tidak baik untuk produktivtas dan keberlanjutan produksi dan perdagangan kopi, sehingga dalam jangka panjang diperlukan upaya untuk mengubah kebiasaan petani dari usaha tani kopi arabika konvensional menjadi usaha tani kopi arabika yang ramah lingkungan.

\section{Metode Penelitian}

Penelitian ini dilakukan di tiga kabupaten di Provinsi Sumatera Utara, yaitu Kabupaten Simalungun, Tapanuli Utara, dan Dairi. Ketiga kabupaten tersebut berada di wilayah dataran tinggi Sumatera Utara dengan elevasi di atas $1.000 \mathrm{~m}$ dpl. Penelitian dilaksanakan pada bulan Februari-Maret 2017. Data aspek ekologis diperoleh dari 90 rumah tangga petani di Kabupaten Dairi dan Kabupaten Tapanuli Utara yang diolah dari data survei yang dilakukan Universitas Simalungun (2011), serta 120 rumah tangga petani di Kabupaten Simalungun. Sampel petani untuk mengetahui determinan produksi adalah 120 rumah tangga petani kopi arabika di Kecamatan Sidamanik, Kecamatan Pamatang Sidamanik, dan Kecamatan Dolok Pardamean di Kabupaten Simalungun. Lokasi penelitian dapat dilihat pada Gambar 1 dan Gambar 2. Pemilihan lokasi penelitian dilakukan dengan metode multi-stage cluster sampling, sedangkan penentuan responden rumah tangga petani dilakukan dengan metode sampel acak sederhana. Metode multi-stage cluster sampling digunakan karena terdapat enam tahap penentuan sampel, yaitu (1) penentuan kabupaten, (2) penentuan kecamatan, (3) penentuan desa, (4) penentuan kelompok tani, (5) penentuan anggota kelompok tani, dan 


\section{Aspek Ekologis dan Determinan Produksi Kopi Arabika Spesialti di Wilayah Dataran Tinggi. .}

(6) penentuan sampel petani. Metode ini merujuk pada Nazir (2009). Pengumpulan data usaha tani dilakukan dengan metode survei menggunakan daftar pertanyaan (kuesioner) melalui tenaga enumerator yang telah dilatih. Tahapan pelaksanaan penelitian dapat dilihat pada Tabel 1 dan Tabel 2.

Karakteristik ekologis usaha tani kopi arabika spesialti dianalisis secara deskriptif berdasarkan tiga aspek, yaitu jumlah pohon pelindung, kegiatan konservasi lahan, dan sistem usaha tani kopi arabika. Variabel ekologis sebagai determinan produksi kopi arabika dianalisis secara kuantitatif dengan menggunakan persamaan regresi ganda. Data diolah dengan menggunakan program SPSS versi 24.

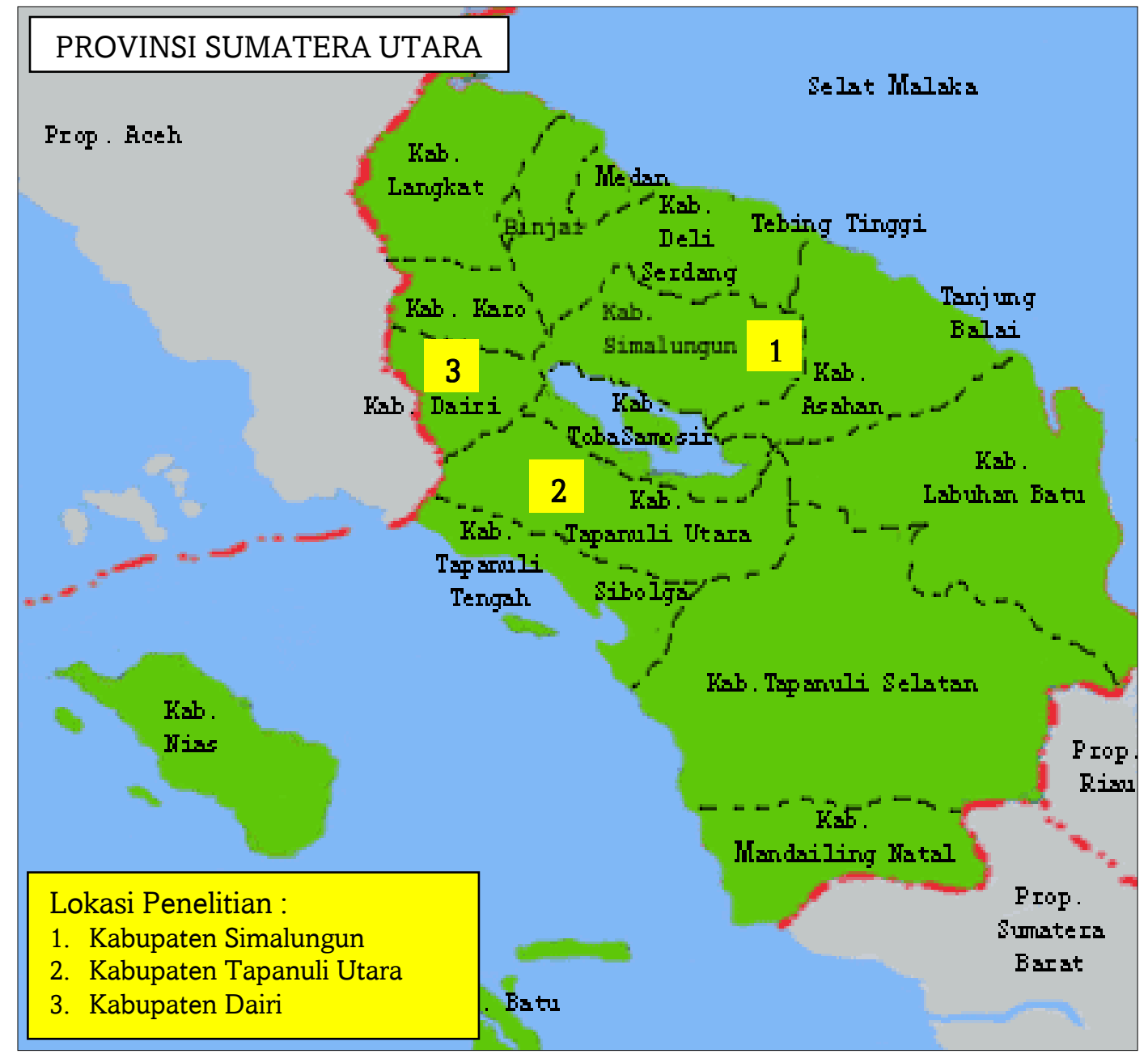

Sumber: Dimodifikasi dari Peta Provinsi Sumatera Utara, 2017

Gambar 1. Peta Lokasi Penelitian untuk Data Aspek Ekologis Usaha Tani Kopi Arabika 


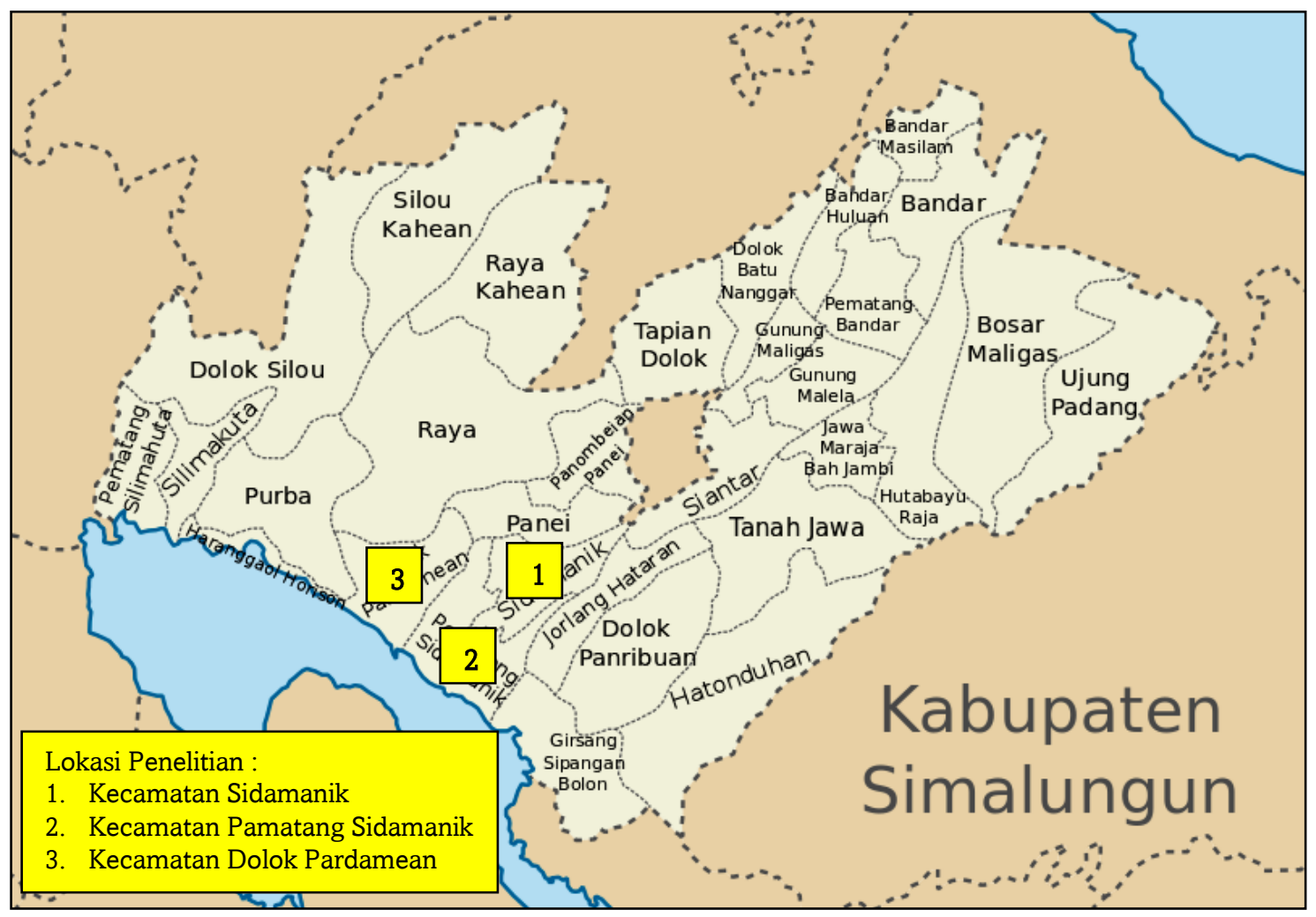

Sumber: Dimodifikasi dari Peta Kabupaten Simalungun, 2017

\section{Gambar 2. Peta Lokasi Penelitian untuk Data Determinan Produksi Kopi Arabika}

Persamaan regresi ganda yang digunakan dalam penelitian ini adalah:

$$
Y=a+b_{1} x_{1}+b_{2} x_{2}+b_{3} x_{3}+b_{4} x_{4}+b_{5} x_{5}
$$

Keterangan:

$\mathrm{Y}=$ produksi kopi arabika (kg/tahun);

$\mathrm{X}_{1}=$ jumlah pohon pelindung (pohon/ha);

$\mathrm{X}_{2}=$ rasio biaya pupuk organik dibandingkan dengan biaya total pupuk (\%);

$\mathrm{X}_{3}=$ variabel dummy pemangkasan tanaman kopi $(1=$ petani melakukan pemangkasan tanaman kopi; 0 = lainnya);

$\mathrm{X}_{4}=$ variabel dummy kegiatan konservasi lahan $(1=$ petani melakukan minimal satu dari pengggunaan mulsa kulit kopi, pembuatan teras, dan/atau rorak; $0=$ petani tidak melakukan kegiatan konservasi lahan);

$\mathrm{X}_{5}=$ variabel dummy pengendalian hama penggerek buah kopi $(1=$ pengendalian secara terpadu; 0 = lainnya). 
Tabel 1. Tahapan Penentuan Sampel dengan Metode Multistage Cluster Sampling

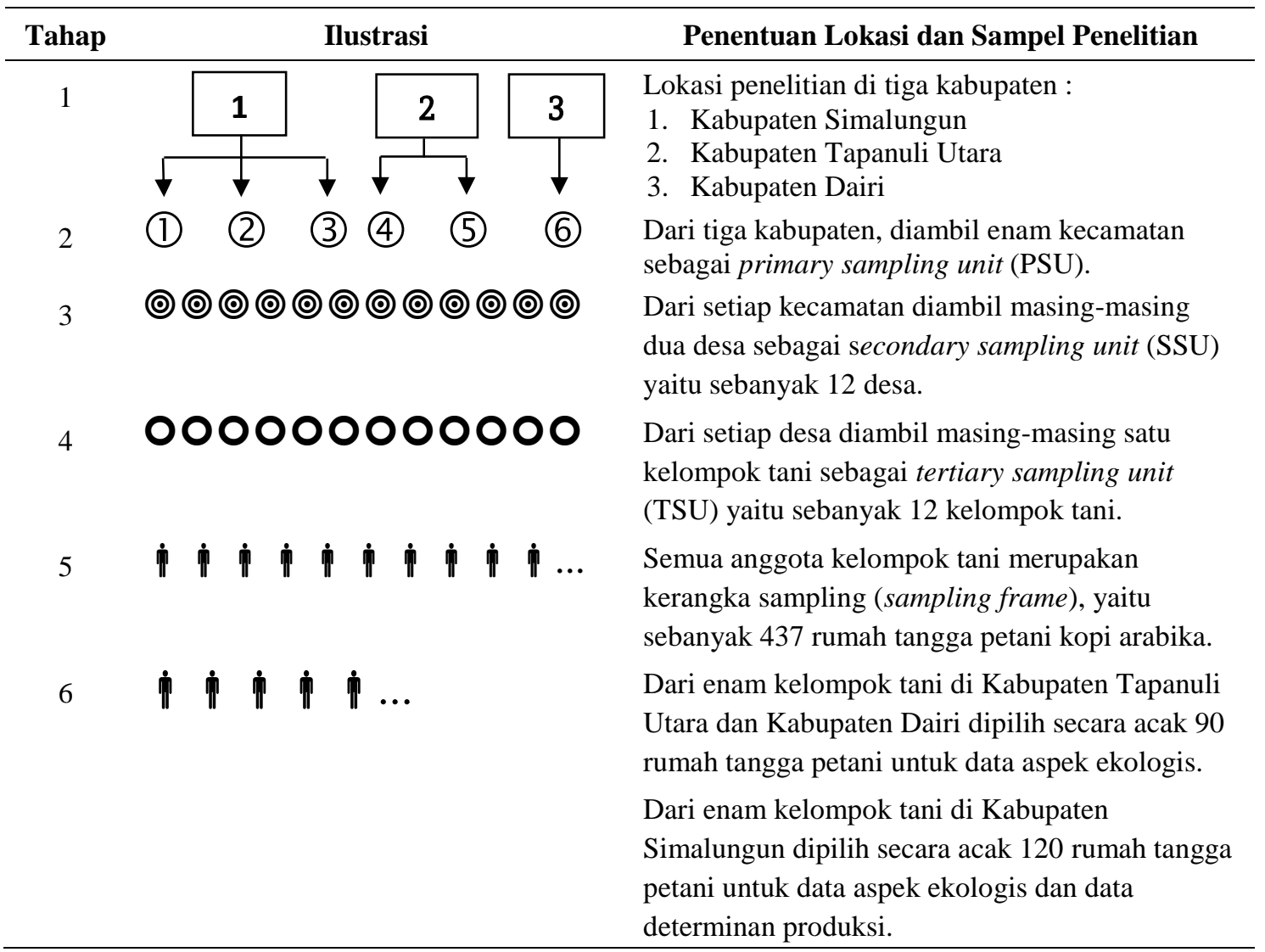

Sumber: Analisis Penulis, 2017

Pengujian yang dilakukan berkaitan dengan persamaan regresi ganda tersebut adalah: (1) uji koefisien determinasi $\left(R^{2}\right)$ untuk mengetahui tingkat kebaikan persamaan yang digunakan; (2) uji $\mathrm{F}$ untuk mengetahui pengaruh semua variabel bebas $\left(\mathrm{X}_{1}, \mathrm{X}_{2}, \mathrm{X}_{3}, \mathrm{X}_{4}\right.$, dan $\mathrm{X}_{5}$ ) secara bersama terhadap produksi kopi arabika (Y); dan (3) uji t untuk mengetahui pengaruh masing-masing variabel bebas secara terpisah terhadap produksi kopi arabika.

Tabel 2. Lokasi dan Sampel Penelitian

\begin{tabular}{|c|c|c|c|c|c|}
\hline Kabupaten & Kecamatan & Desa & $\begin{array}{l}\text { Kelompok } \\
\text { Tani }\end{array}$ & Anggota & $\begin{array}{c}\text { Jumlah Sampel } \\
\text { (Rumah } \\
\text { Tangga) }\end{array}$ \\
\hline \multirow[t]{6}{*}{ Simalungun } & \multirow[t]{2}{*}{ Sidamanik } & Bah Butong 2 & Kebun Sayur & 27 & 20 \\
\hline & & Manik Hataran & Karya & 40 & 20 \\
\hline & \multirow{2}{*}{$\begin{array}{l}\text { Pamatang } \\
\text { Sidamanik }\end{array}$} & Sait Buttu & Karya Putra & 40 & 20 \\
\hline & & Simantin & Gapermas & 44 & 20 \\
\hline & \multirow{2}{*}{$\begin{array}{l}\text { Dolok } \\
\text { Pardamean }\end{array}$} & $\begin{array}{l}\text { Siruberube G. } \\
\text { Purba }\end{array}$ & Mari Bersama & 40 & 20 \\
\hline & & $\begin{array}{l}\text { Buttu Bayu P. } \\
\text { Raja }\end{array}$ & Sauhur & 50 & 20 \\
\hline Sub Jumlah & \multirow{3}{*}{ Siborongborong } & & & 241 & 120 \\
\hline \multirow[t]{3}{*}{ Tapanuli Utara } & & $\begin{array}{l}\text { Lumban } \\
\text { Tongatonga }\end{array}$ & Panca Usaha & 35 & 15 \\
\hline & & Bahal Batu III & Bona Pasogit & 28 & 15 \\
\hline & Siatas Barita & Pancur Napitu & Satahi Uli & 39 & 15 \\
\hline
\end{tabular}




\begin{tabular}{|c|c|c|c|c|c|}
\hline Kabupaten & Kecamatan & Desa & $\begin{array}{l}\text { Kelompok } \\
\text { Tani }\end{array}$ & Anggota & $\begin{array}{c}\text { Jumlah Sampel } \\
\text { (Rumah } \\
\text { Tangga) } \\
\end{array}$ \\
\hline & & Simanampang & Panca Usaha & 48 & 15 \\
\hline \multirow[t]{2}{*}{ Dairi } & Sumbul & Tanjung Beringin & $\begin{array}{l}\text { Tanjung } \\
\text { Beringin }\end{array}$ & 25 & 15 \\
\hline & & Pargambiran & Pargambiran & 21 & 15 \\
\hline Sub Jumlah & & & & 196 & 90 \\
\hline Jumlah & & & & 437 & 210 \\
\hline
\end{tabular}

Sumber: Analisis Penulis, 2017

\section{Hasil dan Pembahasan}

\section{Aspek Ekologis}

Aspek ekologis yang dianalisis dalam penelitian ini adalah jumlah pohon pelindung, kegiatan konservasi lahan, dan sistem usaha tani kopi arabika. Jumlah pohon pelindung dihitung untuk setiap luas usaha tani tanpa membedakan jenis pohon pelindungnya, kemudian dikonversi ke satuan hektar. Kegiatan konservasi lahan yang dilakukan petani adalah pengembalian kulit kopi ke kebun sebagai mulsa, pembuatan rorak (parit buntu penampung air), pembuatan teras individu, dan pembuatan teras bangku. Sistem usaha tani kopi arabika yang ada di wilayah penelitian adalah kopi monokultur, kopi berpelindung, kopi tumpangsari, dan kopi multistrata.

Jumlah pohon pelindung pada usaha tani kopi arabika masih jauh dari standar ideal. Rata-rata jumlah pohon pelindung di Kabupaten Simalungun adalah 43 pohon/ha, Kabupaten Tapanuli Utara 38 pohon/ha, dan Kabupaten Dairi 55 pohon/ha. Dengan demikian, rata-rata jumlah pohon pelindung pada usaha tani kopi arabika di Sumatera Utara adalah 45 pohon/ha (Tabel 3). Pohon pelindung yang ditanam petani pada kebun kopi arabika antara lain adalah dadap (Erythrina lithosfera), suren (Tona sinensis), petai (Parkia spiciosa), jengkol (Pithecollobium jiringa), sengon (Paraserianthes falcataria), durian (Durio zibethinus), dan alpukat (Parsea gratissima). Dengan kondisi ini, pohon pelindung pada usaha tani kopi arabika di Sumatera Utara masih perlu ditingkatkan jumlahnya dengan menanam pohon jenis legum seperti lamtoro dan gamal.

Pohon pelindung cenderung mengurangi produksi kopi, namun secara ekologis peran pohon pelindung bagi tanaman kopi memiliki banyak dampak positif (Van Der Vossen, 2005). Pohon pelindung dapat mengurangi temperatur tanah, menahan kekuatan angin dan hujan lebat, mengendalikan erosi pada lahan miring, mengendalikan pertumbuhan gulma, menghasilkan bahan organik, mendaur ulang hara tanah, mengurangi pencucian hara, mencegah pembuahan yang berlebihan dan mati pucuk akibat pengurangan intensitas cahaya, memberikan tambahan penerimaan dari pohon pelindung (papan, kayu bakar, dan buah-buahan), berpotensi mengurangi penyakit hawar daun, memperbaiki cup quality terutama di wilayah kopi suboptimal secara ekologi akibat temperatur tinggi. Jumlah pelindung minimal untuk tanaman kopi arabika varietas Sigarar Utang adalah 400 pohon/ha (Zaenudin, 2009), berlaku juga untuk jenis lamtoro (Leucaena glauca) atau gamal (Glirisidia sepium) (Mawardi, Hulupi, Wibawa, Wiryadiputra, \& Yusianto, 2008).

Tabel 3. Aspek Ekologis Usaha Tani Kopi Arabika Spesialti di Sumatera Utara

\begin{tabular}{lccccc}
\hline \multirow{2}{*}{ Aspek ekologis } & \multirow{2}{*}{ Satuan } & \multicolumn{3}{c}{ Kabupaten } & \multirow{2}{*}{ Rata-rata } \\
\cline { 3 - 5 } & & Simalungun & Dairi & Tapanuli Utara & \\
\hline Jumlah tanaman kopi & pohon/ha & 2.194 & 1.544 & 1.169 & 1.636 \\
\hline
\end{tabular}


Lanjutan Tabe/3

\begin{tabular}{|c|c|c|c|c|c|}
\hline \multirow{2}{*}{ Aspek ekologis } & \multirow{2}{*}{ Satuan } & \multicolumn{3}{|c|}{ Kabupaten } & \multirow{2}{*}{ Rata-rata } \\
\hline & & Simalungun & Dairi & Tapanuli Utara & \\
\hline Produktivitas* & $\mathrm{kg} / \mathrm{ha} / \mathrm{tahun}$ & $2.299(951)$ & $\begin{array}{l}1.212 \\
(501)\end{array}$ & $1.440(596)$ & $1.650(683)$ \\
\hline $\begin{array}{l}\text { Jumlah pohon pelindung } \\
\text { Kegiatan konservasi lahan: }\end{array}$ & pohon/ha & 43 & 55 & 38 & 45 \\
\hline - Mulsa & $\%$ & 90 & 92 & 95 & 92 \\
\hline - Rorak & $\%$ & 4 & 5 & 2 & 4 \\
\hline - Teras individu & $\%$ & 5 & 2 & 2 & 3 \\
\hline - Teras bangku & $\%$ & 1 & 1 & 1 & 1 \\
\hline Sistem usaha tani: & & & & & \\
\hline - Kopi berpelindung & $\%$ & 18 & 53 & 25 & 32 \\
\hline - Kopi monokultur & $\%$ & 35 & 22 & 32 & 30 \\
\hline - Kopi tumpangsari & $\%$ & 33 & 10 & 28 & 24 \\
\hline - Kopi multistrata & $\%$ & 14 & 15 & 15 & 14 \\
\hline
\end{tabular}

Keterangan: * dalam wujud kopi tanduk (parchment), angka dalam kurung setara kopi biji (green bean) Sumber: Data Kabupaten Simalungun berasal dari hasil penelitian, 2017

Data Kabupaten Dairi dan Tapanuli Utara berasal dari survei Universitas Simalungun, 2011

Evizal, Tohari, Prijambada, \& Widada (2012) menyatakan bahwa pohon pelindung menentukan produktivitas buah kopi berkaitan dengan perannya sebagai penghasil serasah dan siklus unsur hara dalam agroekosistem, serta peranannya dalam penaungan tanaman kopi. Peran positif pohon pelindung pada tanaman kopi juga dinyatakan dalam hasil penelitian Dariah, Susanti, \& Fahmuddin (2008). Usaha tani kopi sistem campuran (multistrata) memberikan pengaruh yang lebih baik terhadap kualitas tanah dibandingkan dengan sistem monokultur. Evizal, Prijambada, Widada, \& Widianto (2008) menemukan berbagai layanan lingkungan yang diberikan oleh pohon pelindung, yaitu produksi serasah mengurangi gugur daun kopi dan menekan pertumbuhan gulma. Produksi serasah sangat penting menyumbang unsur hara tanah terutama nitrogen

Kegiatan konservasi lahan yang dilakukan petani adalah mengembalikan kulit buah kopi ke kebun sebagai mulsa (92\%), membuat teras individu (3\%), membuat rorak (4\%), dan membuat teras bangku (1\%). Kulit buah kopi yang memperbaiki struktur tanah dapat meningkatkan pertumbuhan bibit kopi maupun kakao secara efektif (Pujiyanto, 2007). Terdapat interaksi positif antara kulit buah kopi dan pupuk buatan pada variabel bobot basah dan bobot kering tajuk kopi maupun kakao. Kulit buah kopi dengan pupuk buatan bekerja secara sinergis dalam meningkatkan pertumbuhan tanaman. Aplikasi kulit buah kopi meningkatkan keefektifan aplikasi pupuk anorganik. Falahuddin, Raharjeng, \& Harmeni (2016) menyatakan bahwa pupuk organik limbah kulit kopi memberikan pengaruh nyata terhadap tinggi tanaman dan lebar daun.

Sistem usaha tani kopi arabika yang dilakukan petani adalah kopi monokultur (30\%), kopi tumpangsari dengan tanaman semusim (24\%), dan kopi multistrata yang meliputi kopi, pohon pelindung, dan tanaman semusim (15\%). Menurut Verbist, Putra, \& Budidarsono (2004), terdapat empat jenis sistem usaha tani yang dilakukan petani dalam budidaya kopi arabika spesialti di Sumatera Utara yaitu kopi monokultur (sun-coffee), tumpangsari (intercropping), kopi dengan pelindung (simple shade coffee), dan multistrata (multistrata shade coffee). Simple shade coffee adalah sistem usaha tani kopi dengan pohon pelindung tanpa tanaman tumpangsari, sedangkan sistem multistrata adalah kopi ditanam di bawah pohon pelindung serta bercampur dengan beberapa tanaman lain yang memberikan hasil seperti tanaman buah-buahan, sayuran, kacang-kacangan, dan tanaman obat-obatan.

Jumlah pohon pelindung yang masih sedikit pada usaha tani kopi arabika spesialti di wilayah penelitian ini tidak terlepas dari pandangan petani tentang manfaat pohon pelindung (Saragih, 2012). Sebanyak 40\% responden petani belum mengetahui manfaat pohon pelindung bagi tanaman kopi dan konservasi lahan. Sisanya menyatakan pohon pelindung 
bermanfaat menaungi tanaman kopi dari sinar matahari langsung (16\%), pelestarian lingkungan/konservasi lahan (12\%), penahan sinar matahari dan angin (4\%), mengurangi serangan hama dan penyakit, dan meningkatkan kualitas kopi. Sejumlah $40 \%$ responden petani belum mengetahui manfaat pohon pelindung, bahkan $10 \%$ di antara mereka menyatakan bahwa pohon pelindung tidak bermanfaat bagi usaha tani kopi.

\section{Determinan Produksi}

Variabel yang digunakan dalam analisis determinan produksi terdiri dari variabel terikat yaitu produksi kopi arabika (Y) dan lima variabel bebas yaitu jumlah pohon pelindung $\left(\mathrm{X}_{1}\right)$, perbandingan biaya pupuk organik dengan biaya total pupuk organik dan anorganik $\left(\mathrm{X}_{2}\right)$, pemangkasan tanaman kopi $\left(\mathrm{X}_{3}\right)$ kegiatan konservasi lahan $\left(\mathrm{X}_{4}\right)$, dan pengendalian hama penggerek buah kopi $\left(\mathrm{X}_{5}\right)$.

Koefisien determinasi $\left(\mathrm{R}^{2}\right)$ digunakan sebagai ukuran untuk melihat tingkat kebaikan (goodness of fit) dari persamaan regresi ganda yang digunakan. Persamaan regresi ganda dikatakan baik (fit) apabila $\mathrm{R}^{2}$ mendekati nilai 1. F-hitung digunakan sebagai alat untuk uji signifikansi koefisien determinasi atau $\mathrm{R}^{2}$ (Gujarati, 1988). Menurut Pratisto (2009), nilai Fhitung juga dapat digunakan untuk menentukan apakah model yang disusun dapat diterima atau tidak, karena probabilitas (sig) dari F-hitung yaitu $0,000<\alpha(0,01)$, maka model yang disusun dapat digunakan untuk menduga nilai koefisien regresi. Hasil analisis data dengan menggunakan SPSS versi 24 menunjukkan bahwa nilai $\mathrm{R}^{2}$ yang diperoleh adalah sebesar 0,211 yang berarti sebesar $21,1 \%$ variasi produksi dapat dijelaskan oleh semua variabel bebas yang dimasukkan ke dalam persamaan. Sisanya sebesar 78,9\% dapat dijelaskan oleh variabel bebas lain yang tidak dimasukkan ke dalam persamaan. Pada uji F, nilai F-hitung diperoleh sebesar 6,104 dengan nilai sig sebesar 0,000. Nilai sig < dari $\alpha(1 \%)$ berarti bahwa semua variabel bebas secara bersama berpengaruh sangat nyata terhadap produksi. Belum ditemukan hasil penelitian yang sama dengan menggunakan kelima variabel bebas yang digunakan dalam penelitian ini. Secara parsial, Wollni \& Brümmer (2009) menggunakan variabel pemangkasan tanaman kopi, sementara Suwarno, Supriyadi, \& Ruspendi (2005) dan Poudel et al. (2010) menggunakan variabel pupuk organik.

Uji t digunakan untuk menganalisis pengaruh masing-masing variabel bebas terhadap produksi. Hasil yang diperoleh adalah bahwa jumlah pohon pelindung tidak berpengaruh nyata terhadap produksi kopi arabika (Tabel 4). Hasil ini menunjukkan bahwa semakin banyak populasi pohon pelindung tidak signifikan dalam meningkatkan produksi. Biaya pupuk organik yang lebih tinggi juga memberikan pengaruh yang tidak nyata terhadap produksi kopi arabika. Variabel pemangkasan tanaman kopi dan pengendalian hama PBKo berpengaruh sangat nyata terhadap produksi kopi arabika, sedangkan kegiatan konservasi lahan yang dilakukan petani berpengaruh tidak nyata dan positif terhadap produksi kopi arabika.

Tabel 4. Variabel Ekologis Determinan Produksi Kopi Arabika Spesialti

\begin{tabular}{lrrrr}
\hline Variabel ekologis & $\begin{array}{r}\text { Koefisien } \\
\text { regresi }\end{array}$ & $\begin{array}{r}\text { Standard } \\
\text { error }\end{array}$ & t-hitung & Sig. \\
\hline Konstanta & 537,69 & 167,09 & -- & -- \\
Jumlah pohon pelindung $\left(\mathrm{X}_{1}\right)$ & 1,404 & 1,408 & 0,997 & 0,321 \\
Biaya pupuk organik $\left(\mathrm{X}_{2}\right)$ & 0,899 & 4,786 & 0,188 & 0,851 \\
Pemangkasan tanaman kopi $\left(\mathrm{X}_{3}\right)$ & $677,83^{* *}$ & 168,69 & 4,018 & 0,000 \\
Konservasi lahan $\left(\mathrm{X}_{4}\right)$ & 111,49 & 140,39 & 0,794 & 0,429 \\
Pengendalian hama PBKo $\left(\mathrm{X}_{5}\right)$ & $376,55^{* *}$ & 142,64 & 2,640 & 0,009 \\
\hline
\end{tabular}

Keterangan: Tanda ** menyatakan variabel pemangkasan tanaman kopi $\left(\mathrm{X}_{3}\right)$ dan pengendalian hama penggerek buah kopi $\left(\mathrm{X}_{5}\right)$ berpengaruh sangat nyata terhadap produksi kopi arabika spesialti (Y) pada taraf $\alpha=1 \%$

Sumber: Analisis Penulis, 2017 
Pengaruh yang tidak signifikan dari pohon pelindung dan pupuk organik pada penelitian ini memberi implikasi bahwa penerapan sistem usaha tani kopi berpelindung dan kopi multistrata serta penggunaan pupuk organik sebaiknya sejalan dengan upaya peningkatan harga premium melalui sertifikasi kopi berbasis ekologi. Dengan kata lain, usaha tani kopi berpelindung menjadi insentif yang menarik bagi petani jika dan hanya jika peningkatan produksi yang tidak signifikan tersebut dapat dikompensasi dengan harga premium biji kopi di tingkat petani. Penerapan harga premium menjadi konsekuensi logis karena kopi yang terintegrasi dengan pohon pelindung kualitasnya lebih baik (Moreira, Fernandes, \& Tagliaferro, 2008; Van Der Vossen, 2005; Yadessa et al., 2008) dibandingkan dengan usaha tani kopi konvensional.

Penelitian mengenai hubungan antara aspek ekologi pohon pelindung dengan produksi kopi di negara bagian Chiapas-Meksiko menemukan bahwa kultivar kopi, umur tanaman, pengayaan spesies, populasi pohon pelindung, dan kemiringan lahan, menunjukkan pengaruh yang tidak signifikan terhadap produksi kopi. Sementara itu, penutupan tajuk pohon pelindung di atas 50\% dapat menurunkan produksi kopi (SotoPinto, Perfecto, Castillo-Hernandéz, \& Caballero-Nieto, 2000).

Berkaitan dengan pohon pelindung dan pupuk organik, berbagai kajian menemukan bahwa pengaruh kedua variabel lebih ditujukan untuk produksi kopi berkelanjutan, yaitu untuk memperoleh masa produktif yang lebih panjang. Data produksi kopi dari ChiapasMeksiko pada tahun 2010 dari penelitian Arief et al. (2011) dapat dijadikan rujukan. Tanaman kopi dengan pohon pelindung atau kopi yang tumbuh di bawah tutupan hutan menghasilkan $368 \mathrm{~kg} / \mathrm{ha} /$ tahun. Kopi organik dengan pohon pelindung yang tumbuh di bawah tutupan hutan menghasilkan $690-920 \mathrm{~kg} / \mathrm{ha} /$ tahun. Tanaman kopi yang dikelola secara intensif, dengan input kimia dan tanpa pohon pelindung mampu menghasilkan 920$1.610 \mathrm{~kg} / \mathrm{ha} /$ tahun. Adanya produktivitas kopi berpelindung relatif lebih rendah, maka perdagangan yang adil dan menguntungkan bagi petani perlu ditata, antara lain melalui harga premium, pembayaran jasa lingkungan, dan skema perdagangan karbon kopi.

Variabel pupuk organik adalah rasio biaya pupuk organik dengan biaya total pupuk (pupuk kimia dan pupuk organik) yang digunakan untuk tanaman kopi arabika. Hasil ini menunjukkan bahwa semakin banyak biaya pupuk organik dan semakin sedikit biaya pupuk kimia tidak secara signifikan meningkatkan produksi. Hasil ini sejalan dengan penelitian Kadir \& Kanro (2006), yang menemukan bahwa pemberian pupuk organik pada tanaman kopi tidak menunjukkan perbedaan yang signifikan untuk variabel jumlah cabang produksi dibandingkan dengan tanaman kopi tanpa pupuk organik. Hasil yang sama ditemukan oleh Rubiyo, Trisnawati, Guntoro, \& Destialisma (2004) menyatakan bahwa pemberian pupuk organik dengan dosis yang berbeda tidak berpengaruh nyata terhadap jumlah cabang produktif, produksi kopi gelondong per pohon, dan jumlah buah per dompol.

Kegiatan pemangkasan tanaman kopi yang dilakukan petani menjadi variabel determinan penting dalam peningkatan produksi kopi arabika spesialti. Hasil penelitian ini didukung oleh temuan Kadir, Darmawidah, \& Kanro (2004) yang menunjukkan bahwa pemangkasan tanaman kopi berperan dalam memperbaiki pertumbuhan dan komponen produksi tanaman kopi yaitu jumlah cabang produktif, jumlah ruas produktif, dan jumlah bunga tanaman kopi. Cabang-cabang yang dipangkas sangat memengaruhi jumlah cabang dan produksi untuk tahun selanjutnya (Sianturi \& Wachjar, 2016).

Konservasi lahan adalah praktik yang dilakukan petani untuk mempertahankan kelestarian lahan, yaitu dengan perlakuan mulsa, pembuatan rorak, dan pembuatan teras individu atau teras bangku. Hasil ini menunjukkan konservasi lahan tidak langsung memengaruhi produksi, akan tetapi bertujuan untuk menjaga kelestarian lahan untuk menunjang produksi kopi berkelanjutan. Meskipun pengaruh konservasi lahan terhadap produksi tidak signifikan, hasil penelitian ini dinilai cukup baik sebagai pendorong bagi petani untuk meningkatkan konservasi lahan. Berdasarkan statistik deskriptif, 60\% petani kopi arabika telah melakukan konservasi lahan. Metode yang diterapkan adalah $90 \%$ dengan 
perlakuan mulsa yaitu mengembalikan kulit buah kopi ke kebun, 4\% membuat rorak, 5\% membuat teras individu, dan kurang dari $1 \%$ yang membuat teras bangku. Sejalan dengan penelitian Bernas (2011), perlakuan teras dapat mengurangi limpasan dan erosi tanah, serta mengurangi kehilangan hara N, P, dan K dalam tanah.

Penerapan salah satu atau kombinasi metode pengendalian penggerek buah kopi nonkimia merupakan faktor penting untuk mengurangi kehilangan produksi yang selanjutnya berkonsekuensi pada peningkatan produksi kopi arabika spesialti. Penggerek buah kopi merupakan serangga hama paling serius yang merusak tanaman kopi di seluruh dunia dan penyebab penurunan produksi dan kualitas kopi (Vega, 2011). Pengendalian yang dianggap paling efektif adalah memutus daur hidup hama penggerek buah kopi melalui sanitasi kebun yang meliputi tindakan petik bubuk, lelesan, dan racutan (Susilo, 2008). Zaenudin (2009) memperkirakan intensitas serangan penggerek buah kopi mencapai 15\%. Penyebab tingginya intensitas serangan hama ini adalah adanya buah kopi sepanjang tahun yang mengikuti pola sebaran hujan dengan biji berukuran besar dan agak rentan terhadap serangan penggerek buah kopi. Hartatri \& de Rosari (2011) melaporkan serangan penggerek buah kopi di Nusa Tenggara Timur mencapai 5,46\% (Kabupaten Manggarai) dan 81\% (Kabupaten Manggarai Timur). Arief et al. (2011) melaporkan akibat serangan penggerek buah kopi penurunan produksi kopi di Kabupaten Dairi mencapai 20-30\%.

Kondisi tersebut menunjukkan adanya kehilangan produksi yang cukup besar akibat serangan penggerek buah kopi pada tanaman kopi arabika, hanya $1 \%$ petani kopi arabika di Kabupaten Simalungun yang menggunakan brocap trap dan $6 \%$ yang menggunakan jamur Beauveria bassiana untuk mengendalikan PBKo. Sebagian besar petani menggunakan bekas botol aqua sebagai wadah atraktan. Sisanya, 93\% petani, melakukan sanitasi kebun, lelesan, dan/atau racutan. Kendala utama yang dihadapi petani adalah tidak tersedianya perangkap dan biakan jamur Beauveria bassiana di tingkat petani, selain itu pengetahuan petani atas metode perangkap dan penggunaan jamur masih relatif rendah.

Direktorat Jenderal Perkebunan (2011) merilis serangan penggerek buah kopi di Pulau Flores pada kopi tanduk robusta mencapai $21 \%$. Serangan yang tinggi (mencapai $50 \%$ ) juga ditemukan pada buah kopi di Lampung, Bengkulu, dan Sumatera Selatan. Sementara data yang dicatat oleh para eksportir di wilayah Sumatera Utara menunjukkan persentase biji kopi arabika berlubang akibat serangan penggerek buah kopi mencapai $10-17 \%$. Secara nasional, kehilangan panen mencapai $20 \%$ yang setara dengan 62.500 ton kopi biji setara dengan sekitar US\$100 juta per tahun.

\section{Kesimpulan}

Penerapan aspek ekologis pada usaha tani kopi arabika spesialti di wilayah dataran tinggi Sumatera Utara masih belum berkembang. Dari total usaha tani yang diteliti, hanya $32 \%$ petani yang menanam pohon pelindung dengan populasi rata-rata sejumlah 45 pohon pelindung per hektar, dan masih jauh lebih rendah dari rekomendasi yaitu 400 pohon per hektar. Praktik konservasi lahan yang dilakukan petani pada usaha tani kopi arabika spesialti masih dominan dalam bentuk pengembalian kulit buah kopi ke kebun sebagai mulsa. Pembuatan teras bangku, teras individu, dan rorak masih sangat minim dilakukan petani kopi arabika spesialti di wilayah dataran tinggi Sumatera Utara. Berkaitan dengan sistem usaha tani, $46 \%$ petani telah melakukan usaha tani kopi arabika spesialti yang mendukung produksi berkelanjutan yaitu kopi berpelindung dan kopi multistrata. Sisanya sebesar 54\% petani masih menerapkan usaha tani kopi arabika monokultur serta tumpangsari kopi arabika dengan tanaman semusim.

Determinan produksi yang dominan dari aspek ekologis untuk meningkatkan produksi kopi arabika spesiati di wilayah dataran tinggi Sumatera Utara adalah variabel pemangkasan tanaman kopi arabika dan pengendalian hama penggerek buah kopi (PBKo). Hal ini sejalan dengan teori dan beberapa hasil penelitian terdahulu bahwa kegiatan pemangkasan tanaman 
kopi arabika berperan positif dalam pertumbuhan komponen produksi yaitu cabang produktif, ruas produktif, dan jumlah bunga kopi arabika. Pemangkasan yang dilakukan secara rutin berperan positif dalam meningkatkan produksi pada tahun-tahun berikutnya. Aspek ekologis lainnya yaitu variabel pohon pelindung, pupuk organik, dan kegiatan konservasi lahan tidak berpengaruh signifikan sebagai determinan produksi kopi arabika. Dengan kata lain, pohon pelindung, pupuk organik, dan konservasi lahan bukan merupakan determinan produksi kopi arabika spesialti yang penting dalam jangka pendek, akan tetapi bertujuan untuk menjaga kelestarian lahan dan untuk menunjang produksi kopi secara berkelanjutan dalam jangka panjang. Namun, perlu dicatat bahwa determinan produksi dari aspek ekologis pada penelitian ini hanya berperan sebesar $21,1 \%$ yang dilihat dari nilai koefisien determinasi pada persamaan regresi. Peran yang lebih besar diduga ditentukan oleh variabel-variabel dalam aspek sosial dan ekonomi. Oleh karena itu, determinan produksi kopi arabika spesialti dari aspek sosial dan ekonomi menjadi tema penelitian lanjutan yang disarankan.

\section{Ucapan Terima Kasih}

Penulis mengucapkan terima kasih kepada Dekan Fakultas Pertanian dan Ketua Lembaga Penelitian dan Pengabdian kepada Masyarakat (LPPM) Universitas Simalungun atas fasilitasi dalam penelitian dan penulisan artikel ini melalui Bantuan Dana Penelitian (BDP) dan Insentif Artikel Ilmiah Universitas Simalungun.

\section{Daftar Pustaka}

Arief, M. C. W., Tarigan, M., Saragih, R., \& Rahmadani, F. (2011). Panduan sekolah lapangan: Budidaya kopi konservasi, berbagi pengalaman dari Kabupaten Dairi Sumatera Utara. (I. Wijayanto \& F. Mangunjaya, Eds.), Perpustakaan Nasional. Jakarta: Conservation International Indonesia.

Bernas, S. M. (2011). Effect of coffee pulp compost and terrace on erosion, run off and nutrients loss from coffee plantation in Lahat Regency, South Sumatera, 16(2), 161-167. doi:10.5400/jts.2011.16.2.161.

Dariah, A., Susanti, E., \& Fahmuddin, A. (2008). Simpanan karbon dan emisi Co2 lahan gambut. Retrieved from http://balittanah.litbang.pertanian.go.id/ind/dokumentasi/lainnya/ai dariah.pdf?secure=true .

Direktorat Jenderal Perkebunan. (2011). Statistik perkebunan Indonesia: Kopi 2009-2012. Jakarta: Kementerian Pertanian.

Evizal, R., Prijambada, I. D., Widada, J., \& Widianto, D. (2008). Layanan lingkungan pohon pelindung pada sumbangan hara dan produktivitas agroekosistem kopi. Pelita Perkebunan, 25(1), 23-37. Retrieved from https://iccri.net/download/Pelita Perkebunan/Vol 25 No 1 April 2009/Layanan Lingkungan Pohon Pelindung .pdf.

Evizal, R., Tohari, Prijambada, I. D., \& Widada, J. (2012). Peranan pohon pelindung dalam menentukan produktivitas kopi. Jurnal Agrotropika, 171), 19-23.

Falahuddin, I., Raharjeng, A. R. P., \& Harmeni, L. (2016). Pengaruh pupuk organik limbah kulit kopi (Coffea Arabica L.) terhadap pertumbuhan bibit kopi. Jurnal Bioilmi, 2(2), 108-120. Retrieved from http://jurnal.radenfatah.ac.id/index.php/bioilmi/article/download/1135/953.

Gujarati, D. N. (1988). Basic Econometrics (Second). McGraw Hill Book Company.

Hartatri, D. F. S., \& de Rosari, B. (2011). Analisis usahatani dan rantai pemasaran kopi arabika di Kabupaten Manggarai dan Manggarai Timur. Pelita Perkebunan, 271), 55-67. Retrieved from https://iccri.net/download/Pelita Perkebunan/Vol 27 No 1 April 2011/Analisis Usahatani dan Rantai Pemasaran Kopi Arabika.pdf.

International Coffee Organization (ICO). (2017). Total production by all exporting countries. Retrieved from www.ico.org/prices/po-production.pdf.

International Trade Centre (ITC). (2011). Trends in the trade of certified coffee. Technical Paper. Geneva.

Kadir, S., Darmawidah, A., \& Kanro, M. Z. (2004). Pengaruh pemangkasan terhadap pertumbuhan dan komponen 
produksi tanaman kopi. Jurnal Agrivor, 4(1), 15-20.

Kadir, S., \& Kanro, M. Z. (2006). Pengaruh pupuk organik terhadap pertumbuhan dan produksi kopi arabika. Jurnal Agrivigor, 6(1), 85-92.

Kementerian Pertanian. (2010). Pedoman umum pelaksanaan pengembangan/rehabilitasi kopi organik (specialty) tahun 2010. Jakarta: Departemen Pertanian, Direktorat Jenderal Perkebunan.

Kementerian Pertanian. (2016). Outlook Kopi 2016. (L. Nuryati \& A. Yasin, Eds.), Komoditas Pertanian Subsektor Perkebunan. Jakarta: Pusat Data dan Sistem Informasi Pertanian, Sekretariat Jenderal - Kementerian Pertanian. Retrieved from http://epublikasi.setjen.pertanian.go.id/download/file/295-outlook-kopi-2016.

Lewin, B., Giovannucci, D., \& Panayotis, V. (2004). Coffee markets: New paradigms in global supply and demand. World Bank Agriculture and Rural Development Discussion Paper 3. Washington, DC: World Bank. doi:10.2139/ssrn.996111.

Mawardi, S. (2007). Promoting specialty coffee from Indonesia to be protected by Geographical Indication: A case study on Kintamani Bali Arabika. In Seminar on Georaphical Indications (GIs). Phnom Penh, Cambodia.

Mawardi, S. (2008). Geographic coffees from Indonesia and its potential to support world espresso coffee industry. In 39th International Coffee Day Conference. Trieste, Italy.

Mawardi, S. (2009). Establishment of geographical indication protection system in Indonesia, case in coffee. In Worldwide Symposium on Geographical Indications, jointly organized by the World Intellectual Property Organization (WIPO) and the Patent Office of the Republic of Bulgaria, Sofia. Sofia, Bulgaria.

Mawardi, S., Hulupi, R., Wibawa, A., Wiryadiputra, S., \& Yusianto. (2008). Panduan budidaya dan pengolahan kopi arabika gayo. Pusat Penelitian Kopi dan Kakao Indonesia bekerjasama dengan APED, Bappeda NAD dan UNDP.

Moreira, C. F., Fernandes, E. A. D. N., \& Tagliaferro, F. S. (2008). Shaded coffee: A way to increase sustainability in Brazilian Organic Coffee Plantations. In 16th IFOAM Organic World Congress. Modena, Italy.

Nazir, M. (2009). Metode penelitian. Bogor: Ghalia Indonesia.

Ottaway, A. (2007). A rapid assessment of the specialty coffee value chain in Indonesia. Michigan: United States Agency for International Development (USAID).

Perfecto, I., Vandermeer, J., Mas, A., \& Soto Pinto, L. (2005). Biodiversity, yield, and shade coffee certification. Ecological Economics, 54, 435-446. doi:10.1016/j.ecolecon.2004.10.009.

Poudel, K. L., Yamamoto, S., Naoyuki, Y., Nishiwaki, A., \& Kano, H. (2010). Estimation of production function and resource use condition of organic coffee cultivation in different Farm size and altitude categories in the Hill Region of Nepal. European Journal of Scientific Research, 45(3), 438-449.

Pratisto, A. (2009). Statistik menjadi mudah dengan SPSS 17. Jakarta: Elex Media Komputindo.

Pujiyanto. (2007). Pemanfaatan kulit buah kopi dan bahan mineral sebagai amelioran tanah alami. Pelita Perkebunan, 23(2), 159-172.

Rhinehart, R. (2009). What is specialty coffee? Retrieved July 4, 2016, from http://www.scaa.org/?page=RicArtp2.

Rubiyo, Trisnawati, W., Guntoro, S., \& Destialisma. (2004). Pengaruh dosis pupuk kandang sapi terhadap produktivitas dan mutu kopi arabika di Bali. In Prosiding Seminar Nasional Sistem Integrasi Tanaman Ternak (pp. 396-400). Bogor: : Puslitbangnak.

Saragih, J. R. (2012). Pengaruh faktor sosial ekonomi dan ekologi terhadap produksi kopi arabika spesialti dalam pengembangan ekonomi lokal di Kabupaten Simalungun. Universitas Sumatera Utara.

Sianturi, V. F., \& Wachjar, A. (2016). Pengelolaan pemangkasan tanaman kopi arabika (Coffe arabica L.) di Kebun Blawan, Bondowoso, Jawa Timur. Buletin Agrohorti, 4(3), 266-275. Retrieved from journal.ipb.ac.id/index.php/bulagron/article/download/14242/10599.

Soto-Pinto, L., Perfecto, I., Castillo-Hernandéz, J., \& Caballero-Nieto, J. (2000). Shade effects on coffee production at the Northern Tzeltal zone of the State of Chiapas, Mexico. Agriculture, Ecosystems and Environment, $80,61-69$.

Susilo, W. A. (2008). Ketahanan tanaman kopi (cofee spp.) terhadap hama penggerek buah kopi (Hypothenemus Hampei Ferr). Review Penelitian Kopi dan Kakao, 24(1), 1-14.

Suwarno, P., Supriyadi, \& Ruspendi. (2005). Faktor-faktor yang berpengaruh terhadap produksi kopi (Coffea sp.) robusta di Pekon Ciptawaras Kecamatan Sumberjaya, Lampung Barat. In Prosiding Lokakarya Nasional 


\section{Aspek Ekologis dan Determinan Produksi Kopi Arabika Spesialti di Wilayah Dataran Tinggi. .}

Pengembangan Pertanian Lahan Kering (pp. 391-395). Bandar Lampung: BPTP Lampung.

Universitas Simalungun. (2011). Consultant for mentoring coffee farmer logbook and data collection in North Sumatra (Final Report Unpublished).

Van Der Vossen, H. A. M. (2005). A critical analysis of the agronomic and economic sustainability of organic coffee production. Experimental Agriculture, 41(4), 449-473. doi:10.1017/S0014479705002863.

Vega, F. E. (2011). The coffee berry borer: An overview. In Ninety-fifth Annual Meeting, Waikoloa, Hawaii. Pacific Branch of The Entomological Society of America. Retrieved from http://www.ctahr.hawaii.edu/site/ CBBSymposium11.aspx.

Verbist, B., Putra, A. E., \& Budidarsono, S. (2004). Penyebab alih guna lahan dan a terhadap fungsi daerah aliran sungai (DAS) pada lansekap agroforestri berbasis kopi di Sumatera. Agrivita, 26(1), 29-38. Retrieved from www.worldagroforestry.org/sea/Publications/files/book/BK0063-04-4.pdf.

Wahyudi, T., \& Misnawi. (2007). Peluang dan tantangan komoditi kakao dan kopi untuk pasar Uni Eropa. Warta Pusat Penelitian Kopi Dan Kakao Indonesia, 23(3), 118-130.

Wollni, M., \& Brümmer, B. (2009). Productive efficiency of specialty and conventional coffee farmers in Costa Rica: Accounting for technological heterogeneity and self-selection (Discussion Papers 13). Goettingen, Germany. Retrieved from https://ideas.repec.org/p/got/gotcrc/013.html.

Yadessa, A., Burkhardt, J., Denich, M., Wolemariam, T., Bekel, E., \& Goldbach, H. (2008). Effect of different indigenous shade trees on the quality of wild arabica coffee in the Afromontane Rainforests of Ethiopia. In ASIC 22nd International Conference on Coffee Science. Campinas, Brazil.

Zaenudin. (2009). Good agricultural practices and sustainable coffee production (Module Tra). Medan: International Finance Corporation (IFC) and PT. Indo Cafco. 